\title{
NURSERY RHYMES AS A MEANS OF UPBRINGING CHILDREN IN KARAKALPAK CHILDREN'S FOLKLORE
}

\author{
Abdalieva Periuza Isaevna ${ }^{1}$, Amirlan Seydin Elsuyer uli ${ }^{2}$ \\ Department of General pedagogy and psychology \\ Nukus State Pedagogical Institute \\ Nukus, Karakalpakstan, Uzbekistan
}

Article DOI: https://doi.org/10.36713/epra8752

DOI No: 10.36713/epra8752

\begin{abstract}
The article deals with the importance of nursery rhymes as a means of upbringing children in Karakalpak children's folklore. In the aticle, Karakalpak, Kazakh and Kyrgyz children's folklore have been analyzed. Descriptive and comparative methods analyzes are used in this paper. Also, some examples of nursery rhymes from Karakalpak children's folklore have been analyzed and their meanings are explained in the English language.

KEY WORDS: upbringing, Karakalpak, children's folklore, nursery rhymes.
\end{abstract}

\section{INTRODUCTION}

In many periods, children's folklore reflects experienced by humanity, and currently, it also constitutes a set of existing genres. In the field of folklore studies of the peoples of the world, creations dedicated to children and performed by them are the main core for significant research and are studied on a large scale. Especially, the importance of the genre in the development of the art of words is determined by considering in the composition of affectionatepoetic samples - jokes that are the leader of children's verbal games $[5$, p. 46-51]. In the children's folklore of the peoples of Central Asia, nursery rhymes (jokes) were first analyzed in the studies of $\mathrm{O}$. Safarov, they began to be called "qiziqmachoqlar". In Kazakh folklore studies, this genre is studied under the names "suramaqtar" or "qiziqtamalar". And in the Kyrgyz children's folklore they are called "suroo-joop aytymdar". The researcher of Karakalpak children's literature I. Kurbanbayev calls such samples as "children's entertainment and play songs".

Nursery rhymes are used to attract children to entertaining games, increase the ability to memorize and interest in the art of words, and they are one of the existing genres in Karakalpak folklore. Previously, this genre was called "sawiqlamalar". In folk art, the word "sawik" meant "entertainment", "fun", "performance". In the explanatory dictionary, meanings close to this are given [4, p. 187].
Basically, the Karakalpak name of this genre "sawiqlamalar", consisting of interesting questions and answers, and it has similar grounds and its formation as children's creativity has been determined for centuries.

\section{LITERATURE REVIEW}

Nursery rhymes in the Karakalpak folklore "Ha'kke qayda?”, “Tu'lkishek”, “G'aq, g'aq g'arg'alar!”, “Tu'ye, tu'ye - tu'yeler" are multivariate and widespread examples of the nursery rhymes genre. In addition to helping parents, to learn by heart, children themselves can easily memorize the texts of nursery rhymes. A striking example of this is the number of created national versions of the genre. The main feature of jokes is rhyming questions and answers. Since the events in them are built on short plots, they resemble small fairy tales. Taking into consideration of these aspects, a famous Tatar folklorist N. Isanbet called them "fairy-talelike". The consistent presentation of such a play on words not only awakens the interest of children, but also makes them think for themselves, broadens their horizons. With the help of memorization and repetition of nursery rhymes, children will communicate with nature, and they can get acquainted with the world of animals.

Sometimes they speak directly to insects, for example: "Gu'belek, gu'belek!”, "Qon'izaq, Qon'izaq!”, "Qumirsqa, qumirsqa”, "Miltiqshi, 
miltiqshi", "Xanqizi, xanqizi" and communicate with them in private, but with living beings whom they have never met with the help of a third person. In the nursery rhyme "Ha'kke qayda?" this situation that catches the eye can be seen:

- Ha'kke qayda? (Where is the bird (ha'kke is a kind of bird?)

- Uyasinda. (In the nest)

- Neg'ip otir?(What is it doing?)

- Keste tigip otir. (Embroiding)

-Kestesiqanday?(Whatkind of embroidery?)

hand).

- Alaqanday... . (From the palm of your

It is these actions of the bird that make children think, especially girls. They are reminded that they should not just sit at home spending idle time, they should be busy with doing something, or help their parents to do some work around the house. This nursery rhyme later turned into a children's outdoor game [6, p. 12]. And the reason for this is that N. Davkaraev "Children's song", K. Ayimbetov's "Children's game" is precisely in this $[3$, p. $137 ; 1$, p. 49].

\section{RESULTS AND DISCUSSION}

If we consider and look closely at the simple and short examples of traditional nursery rhymes, we can see that they appeared on the basis of a conversation between parents and children. A striking example of this is the joke "Ha'kke qayda?", which is very popular among the nursery rhymes performed by mothers. And nursery rhyme, known as "Tu'lkishek", has been considered the most versatile artistic examples of this genre, for example:

- Túlki, túlki-túlkishek! (Fox, fox) go at night?)

Túnde qayda baramı? (Where will we

- Mamam úyine baramiz. (We will go to grandma's home)

- Mamań bizge ne berer? (What will grandma give us?) goat milk)

- Eshki sawip sút berer. (She will give us

_ Serke soyıp et berer. (She will slaughter a goat, give meat)

it?)

- Onı qayda qoyamı?? (Where do we put

- Tal túbine qoyamiz. (We will put under the

tree)

away?)

- Iyt áketse qáytemiz? (What if the dogs take the dog)

- Iyt awzınan alamız. (We will take it from

- Qus áketse qáytemiz? (What if the bird carries away?)

the bird)

- Qus awzınan alamız. (We will take it from
- Qumǵa tússe qáytemiz? (What if we drop it on the sand?) and wash it

- Qaǵıp-qaǵıp juwamız. (We will shake it off in water?

- Suwǵa tússe qáytemiz? (What if we drop it

- Suw astinan tawamiz. (We will get it out from under the water)

by the flow?)

- Aǵıp ketse qáytemiz? (And if carried away up on the boat)

- Qayıqqa minip quwamiz. (We will catch catch up?)

- Jetkizbese qáytemiz? (And if we don't on fish!)

- Balıqqa minip quwamı!! (We will catch up

Most of the nursery rhymes called "Tu'lkishek" end so interestingly. The transition from one action to another, the dynamic development of the event form makes children's ability to make quick decisions. This, of course, is one of the ways of national education, which appeared from the interest of the child in the play on words. Under the name "Tu'lkishek", there are also fairy tales, children's comic sayings, various outdoor games. Moreover, there is information about the transformation of such creations into the favorite creations of Karakalpak children over the course of several centuries. Also, even some of their samples have found a place in Uzbek and Kazakh folklore. Negotiations with the smallest of insects - ants, constitute a separate cycle. There are a lot of fables about ants in the Karakalpak folklore.

In some fables and nursery rhymes, there is close connection with interesting events and such positive qualities of an ant as tolerance to hunger, reconciliation with difficulties, flexibility, and others are described. Under the influence of such fables, nursery rhymes appear, they inspire imagination of children, further they will increase their curiosity to learn the secrets of nature, for example:

- Qumırsqa, qumırsqa, (Ant, ant) with a spot?)

Basiń nege qasqa? (Why is your head smart?)

- Aqulım kóp shiǵar?! (May be I am very thick?)

- Quyrıǵı́n nege juwan? (Why is your tail strong?)

- Kúshim kóp shıǵar?! (May be I am very

- Beliń nege jińishke? (Why is your waist so thin?)

- Shúkirligim kóp shiǵar?! (Maybe I am grateful for everything I have?!)

- Ayaǵı́n nege slydam? (Why are your legs thin?) 
lot?!) - Júrisim kóp shıǵar?! (Maybe I walk a
fast?) - Júrisiń nege jıldam? (Why do you walk
to do?!) - Jumisim kóp shıǵar?! (Maybe I have a lot
Thus, through these questions and answers, a person is set as an example of the restlessness, hard work, and tolerance of an ant. Also, it is known that the nursery rhyme "Who is stronger?" ends with the ant eventually defeating everyone. The reason for this is that in myths and legends, an ant is considered the personification of hard work, patience. For example, during one of the heavy, bloody battles, the seriously wounded Amir Temur, who was lying very weak, with exhausted patience, lost hope, and sees one ant who carried a grain on him and could not climb a small hillock fifty times, but he still did not give up and fifty-first time, finally, climbed on it lastly. Amir Temur made a conclusion from what he saw, and made it a rule to never give up after the first failure.

\section{CONCLUSION}

Thus, in general, nursery rhymes in the creativity of the peoples of Central Asia have been a folklore form that has existed for a long time. Samples inherent in the genre are "Ha'kke qayda?", "Tu'lkishek", "Quslar qayda barasiz?”, "Tu'ye tu'ye, tu'yeler ...", with the creation of interesting question-and-answer dialogues of this type, they have been updated and revived with renewed vigor. Therefore, the children sang any line that they themselves knew to the existing pattern. For this reason, they had a variety of options, turned into creations that the kids themselves could sing and took a strong place in children's folklore.

\section{REFERENCES}

1. Ayimbetov Q. Karakalpak folklore. (In Karakalpak language). Nukus: Karakalpakstan, 1977.

2. Amirlan S.E. Aytpishlar // Scientific session of Karakalpak Research Institute of Humanities: [Eresource]. Nukus, 2015.

3. Davqaraev N. A complete collection of works. (In Karakalpak language). II Volume. Nukus: Karakalpakstan, 1977.

4. TSKKYa - Explanatory dictionary of the Karakalpak language. (In Karakalpak language). IV Volume. Nukus: Karakalpakstan, 1992.

5. Melnikov M.N. Russian children's folklore. (In Russian language). M.: Prosveshenie, 1987.

6. Shlmanov P. National children's games. Nukus: Bilim, 1996. 